\title{
Sphagneticola Trilobata (L.) Pruski (Asteraceae) Methanol Extract Induces Apoptosis in Leukemia Cells through Suppression of BCR/ABL
}

\author{
Hoang Thanh Chi, Nguyen Thi Lien Thuong and Bui Thi Kim Ly *(D) \\ Faculty of Food Technology, Institute of Applied Technology, Thu Dau Mot University, \\ Thu Dau Mot City 820000, Binh Duong Province, Vietnam; chiht@tdmu.edu.vn (H.T.C.); \\ thuongnt1@tdmu.edu.vn (N.T.L.T.) \\ * Correspondence: lybtk@tdmu.edu.vn
}

Citation: Chi, H.T.; Thuong, N.T.L.; Ly, B.T.K. Sphagneticola Trilobata (L.) Pruski (Asteraceae) Methanol Extract Induces Apoptosis in Leukemia Cells through Suppression of BCR/ABL. Plants 2021, 10, 980. https://doi.org/ 10.3390/plants10050980

Academic Editor: Octavian Tudorel Olaru

Received: 9 April 2021

Accepted: 11 May 2021

Published: 14 May 2021

Publisher's Note: MDPI stays neutral with regard to jurisdictional claims in published maps and institutional affiliations.

Copyright: (C) 2021 by the authors Licensee MDPI, Basel, Switzerland. This article is an open access article distributed under the terms and conditions of the Creative Commons Attribution (CC BY) license (https:// creativecommons.org/licenses/by/ $4.0 /)$.
Abstract: We will study the effects of the methanol extract of Sphagneticola trilobata (L.) Pruski (Asteraceae) (MeST) on the growth of leukemia cells that may contain the $B C R / A B L$ gene. This study also clarifies the mechanism of this effect on these cells. For this purpose, the cells harboring wildtype BCR/ABL, imatinib-resistant BCR/ABL (K562 and TCCYT315I), or Ba/F3 cells transfected with wild-type or mutant $B C R / A B L$ genes were used. The results showed that MeST effectively inhibited the viability of leukemia cells in both a dose- and time-dependent manner. The effect of MeST seems to be more sensitive in the cells that carry imatinib-resistant BCR/ABL (especially the T315I $\mathrm{BCR} / \mathrm{ABL}$ mutation) than those with wild-type BCR/ABL. Furthermore, we have demonstrated that the death caused by MeST is apoptosis and the treatment with MeST could suppress the expression of BCR/ABL, subsequently altering the downstream cascade of BCR/ABL such as AKT and MAPK signaling. In conclusion, MeST has been able to suppress the growth of leukemia cells harboring $\mathrm{BCR} / \mathrm{ABL}$. The mechanism of the anti-leukemic effect of MeST on cells harboring imatinib-resistant $\mathrm{BCR} / \mathrm{ABL}$ mutations could be due to the disruption of the BCR/ABL oncoprotein signaling cascade.

Keywords: Sphagneticola trilobata; antileukemia; chronic myeloid leukemia (CML); BCR/ABL

\section{Introduction}

Chronic myeloid leukemia (CML) is a type of cancer found in the blood and bone marrow. This disease is characterized by a reciprocal $t(9 ; 22)$ chromosomal translocation, resulting in the formation of the Philadelphia $(\mathrm{Ph})$ chromosome containing the $B C R / A B L$ gene [1]. CML patients have the benefit of treatment due to the introduction of imatinib, a tyrosine kinase inhibitor (TKI) [2]. However, the imatinib resistance emerged as a serious problem. As least four generations of TKIs have been developed and shown to be potentially effective in treatment [3]. However, not all the TKI resistance problems are solved.

There are a large number of studies focusing on the mechanism of resistance. One of the reasons is the mutations on the sequences of $B C R / A B L$ [3]. Moreover, the mechanism of resistance also counts for some, such as the genomic amplification of $B C R / A B L$ [4]. Focusing on blocking the activation of BCR/ABL is very effective as imatinib has done, but it may not be the most perfect solution. A combination of reagents that have different effects of action may solve the problem of drug resistance [5].

Traditional medicine, focusing on herbal medicine with healthy activities, received largely concerns from researchers. The anticancer effect of herbal medicine is shown in many researches, but the mechanism of anticancer effect from it is difficult to clarify. It could be the combination of a variety of actions [6]. Many plant-derived medicines have been used in the community for a long time, demonstrating their safety in part. Therefore, it is a potential resource for humans to find effective therapeutic reagents for treatment. In 
fact, certain cancer chemotherapeutic drugs obtained from natural origin have had excellent effects [7]. The roles of traditional medicine have been established in Vietnam and are progressively contributing to supporting the healthcare system as an alternative treatment. There are more than 12,000 plants and no less than 2500 species used in ethnomedicine [8,9], but few Vietnamese plants have been studied for cancer [10-12].

Sphagneticola trilobata (L.) Pruski is a species of the genus Sphagneticola (Asteraceae family) and has many synonyms, but the most common one is Wedelia trilobata (L.) Hitchc. S.trilobata native to South America, Central America, Mexico and the West Indies. It has been widely found in Bangladesh, India, China, Malaysia, Indonesia, Vietnam, Cambodia and Myanmar. It thrives in valleys, ditches, wet roads, cropland, natural forests, pastures, coastal areas and urban areas. In Vietnam, S.trilobata is often referred to as Sai dat ba thuy, Sai dat kieng, Son cuc ba thuy, Cuc xuyen chi. It is a wild and highly invasive plant, but it is also cultivated and used by the Vietnamese as a traditional medicine. Previous studies state that the methanol flower extract of S.trilobata had excellent antioxidant activities [13]. The aqueous extracts of S.trilobata exerted a considerable hypoglycemic effect and had antidiabetic potential activity [14]. The methanol extract of the root, stem, leaves and flowers of $S$. trilobata was found to be significant against the following three bacteria: Pseudomonas aeruginosa, Staphylococcus aureus and Salmonella typhi [15]. S.trilobata methanol extract inhibited the growth of the human megakaryoblastic leukemia cell line MEG-01 with a half maximal inhibitory concentration $\left(\mathrm{IC}_{50}\right)$ value of around $80 \mu \mathrm{g} / \mathrm{mL}$ [16]. Sesquiterpene lactone compound isolated from $S$. trilobata significantly inhibited the proliferation of HL-60, K-562, SI80, HepG2 and MCF-7 cells, with an $\mathrm{IC}_{50}$ value of $4 \mu \mathrm{g} / \mathrm{mL}, 6.5 \mu \mathrm{g} / \mathrm{mL}$, $8 \mu \mathrm{g} / \mathrm{mL}, 24 \mu \mathrm{g} / \mathrm{mL}$ and $36 \mu \mathrm{g} / \mathrm{mL}$, respectively [17].

In this study, we test the antileukemic effect of the methanol extract of S.trilobata (MeST) on CML cells harboring $B C R / A B L$. The results show that MeST has a growth inhibitory effect, not only in the imatinib-sensitive cells but in the imatinib-resistant cells. Moreover, we demonstrated that the MeST-induced cell death could be due to the disruption of the $\mathrm{BCR} / \mathrm{ABL}$ signaling cascade in these cells.

\section{Results}

\subsection{Effect of MeST on Cells Harbouring BCR/ABL Gene}

In this study, we tested the effect of MeST on the growth of cells that carry the fusion gene $B C R / A B L$ (wild-type or mutation). Cell lines were treated with different concentrations of extract for 2 days. Then trypan blue test was used to calculate the growth of the cell. The result showed that MeST could suppress the growth of human leukemic K562 cells as well as TCCY-T315I cells in a dose-dependent manner (Figure 1). The same effect could be observed on the transfected $\mathrm{Ba} / \mathrm{F} 3$ cells (Ba/F3 cells were transfected with Y253H, E279K and T315I construct) (Figure 1). This observation is very interesting because MeST could overcome the imatinib resistance in cells that harbor T315I mutation in $B C R / A B L$.

To check whether the effect of MeST on cells is a time-dependent effect, we set up the time course experiment in TCCY-T315I cells. The result show that the cells treated with the control (DMSO alone) grow well after $48 \mathrm{~h}$. However, the cells treated with $50 \mu \mathrm{g} / \mathrm{mL}$ of the MeST are not grown, and even undergo degradation, after $48 \mathrm{~h}$ of being cultured (Figure 2). This result again confirmed that MeST could suppress the growth of cells.

Since the SI value indicates the differential behavior of the extract, the more selective it is, the higher the SI value. An SI value greater than 3 units indicates the general toxicity of the pure compound [18]. In this study, the SI value was expressed as an $\mathrm{IC}_{50}$ value of the Vero cell compared to an $\mathrm{IC}_{50}$ value of the cancer cell line. As shown in Figure 3A, the effect of MeST on Vero cells is significantly less sensitive compared to other cells. The results showed that the SI values of MeST were higher than 3 (Table 1 and Figure 3B), indicating that the MeST had potent cytotoxic activity and good selectivity against leukemia cells with $B C R / A B L$. 


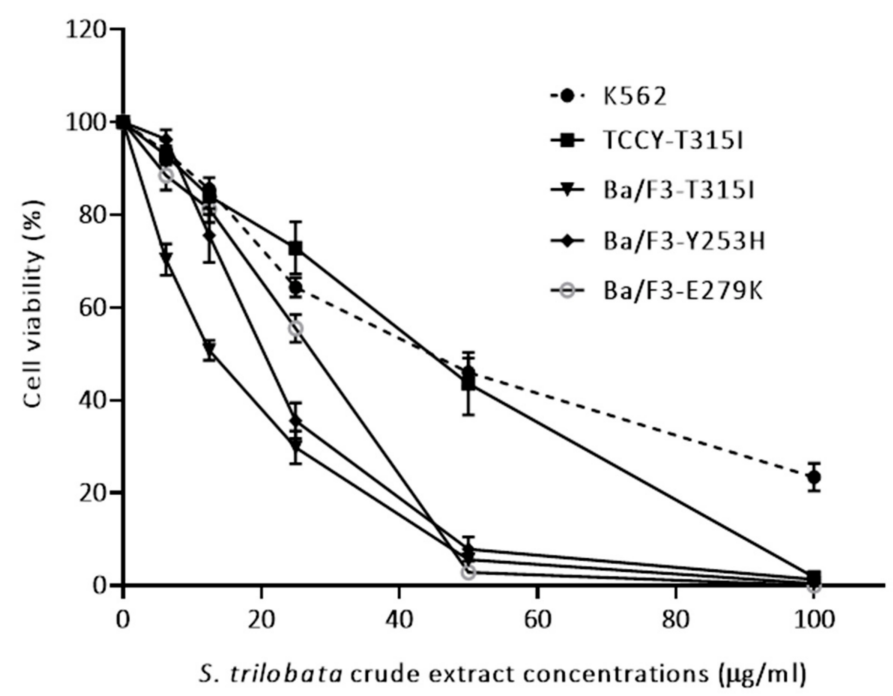

Figure 1. Cell growth inhibition induced by MeST in a dose-dependent manner. MeST were added at different concentrations (6.25 to $100 \mu \mathrm{g} / \mathrm{mL}$ ) to K562, TCCY-T315I, Ba/F3-Y253H, Ba/F3-E279K, and $\mathrm{Ba} / \mathrm{F} 3-\mathrm{T} 315 \mathrm{I}$ cells for $48 \mathrm{~h}$ and cell viability assays were performed as described in materials and methods. Results are presented as a percentage of death from treated MeST cells in comparison with non-treated MeST cells (handled with DMSO at the same concentration as MeST). The experiments were performed in triplicate. $p$ value $<0.0001$ for all tested cells.

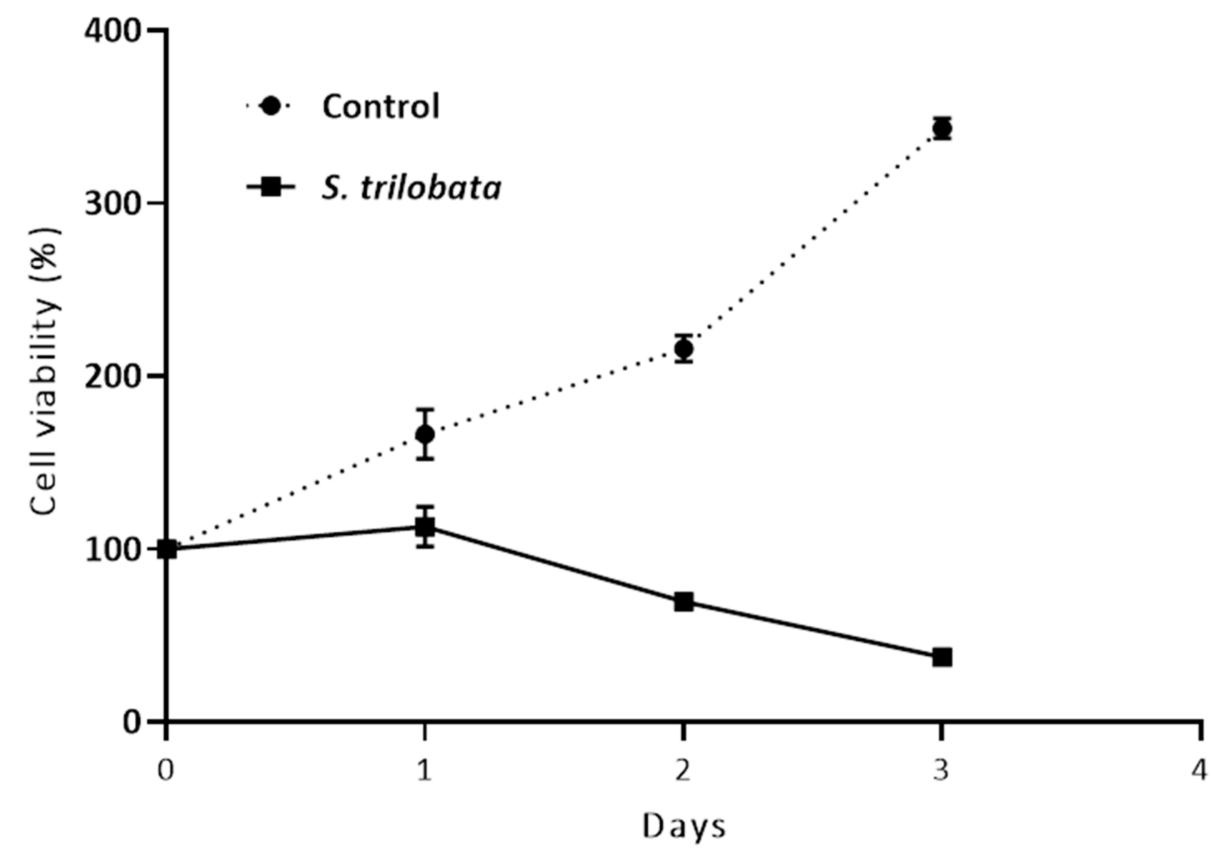

Figure 2. Effect of MeST on TCCY-T315I cells is a time-dependent manner. MeST $(50 \mu \mathrm{g} / \mathrm{mL})$ were added to TCCY-T315I cells for various time periods (0 to 3 days) and cell viability assays were determined as described in materials and methods $(p<0.0001)$. 
A

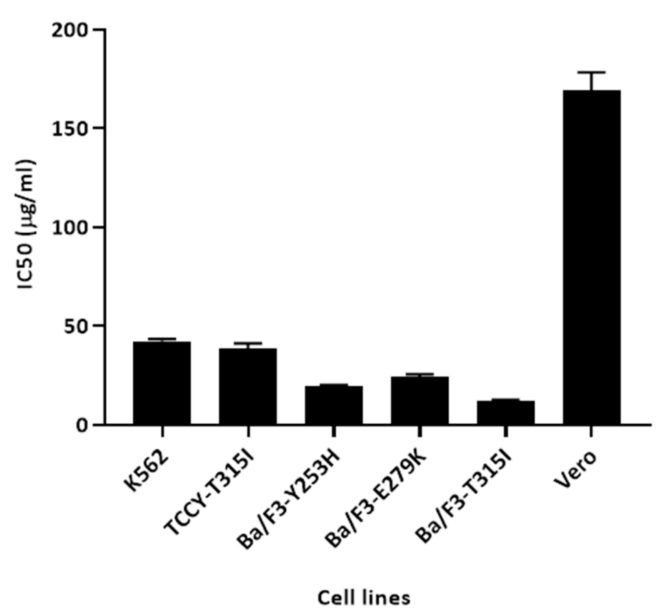

B

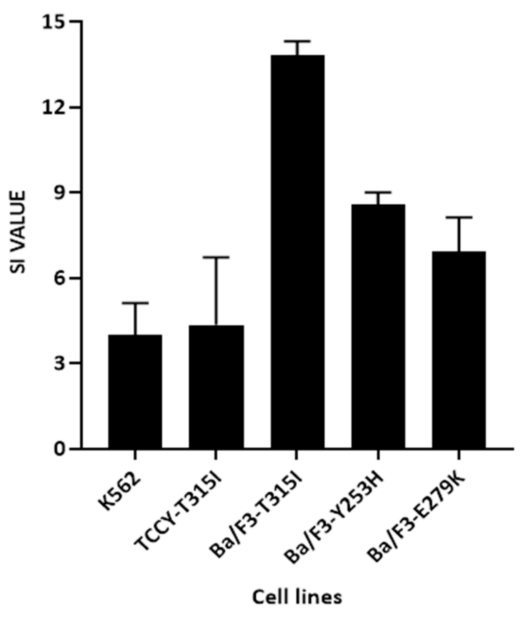

Figure 3. The IC 50 and SI values of MeST on cells. (A) The IC 50 value of MeST on K562, TCCY-T315I, Ba/F3-T315I, Ba/F3-Y253H, Ba/F3-E279K, and Vero cell. (B) The SI value of MeST on K562, TCCYT315I, Ba/F3-T315I, Ba/F3-Y253H, Ba/F3-E279K were calculate by dividing IC $_{50}$ against Vero cells to $\mathrm{IC}_{50}$ against leukemia cells.

Table 1. The $\mathrm{IC}_{50}$ value and selectivity index of MeST on cell growth of leukemia cell lines.

\begin{tabular}{ccc}
\hline \multirow{2}{*}{ Leukemia Cell Lines } & \multicolumn{2}{c}{ MeST } \\
\cline { 2 - 3 } & IC $_{50}(\mu \mathrm{g} / \mathrm{mL})$ & SI \\
\hline K562 & $42.31 \pm 1.13$ & 4.00 \\
\hline TCCY-T315I & $38.78 \pm 2.37$ & 4.36 \\
\hline $\mathrm{Ba} / \mathrm{F} 3-\mathrm{T} 315 \mathrm{I}$ & $12.23 \pm 0.51$ & 13.81 \\
\hline $\mathrm{Ba} / \mathrm{F} 3-\mathrm{Y} 253 \mathrm{H}$ & $19.68 \pm 0.41$ & 8.59 \\
\hline $\mathrm{Ba} / \mathrm{F} 3-\mathrm{E} 279 \mathrm{~K}$ & $24.41 \pm 1.21$ & 6.92 \\
\hline
\end{tabular}

\subsection{Cell Morphological Changes Using Phase Contrast Inverted Microscope}

Morphological changes are a sign of apoptosis [19,20]. In this assay, the morphological properties of the cells were determined by a phase contrast inverted microscope after exposure to different concentrations of MeST (50-100 $\mu \mathrm{g} / \mathrm{mL}$ ). As shown in Figure 4, all the treated cells are affected by MeST. The cells seem to be shrunken $24 \mathrm{~h}$ after being treated with $50 \mu \mathrm{g} / \mathrm{mL}$ or $100 \mu \mathrm{g} / \mathrm{mL}$ of MeST. This observation is compatible with the result shown in Figure 1. Changes in the cell morphology of TCCY-T315I were also found in both the treated and untreated cells (Figure 5). 


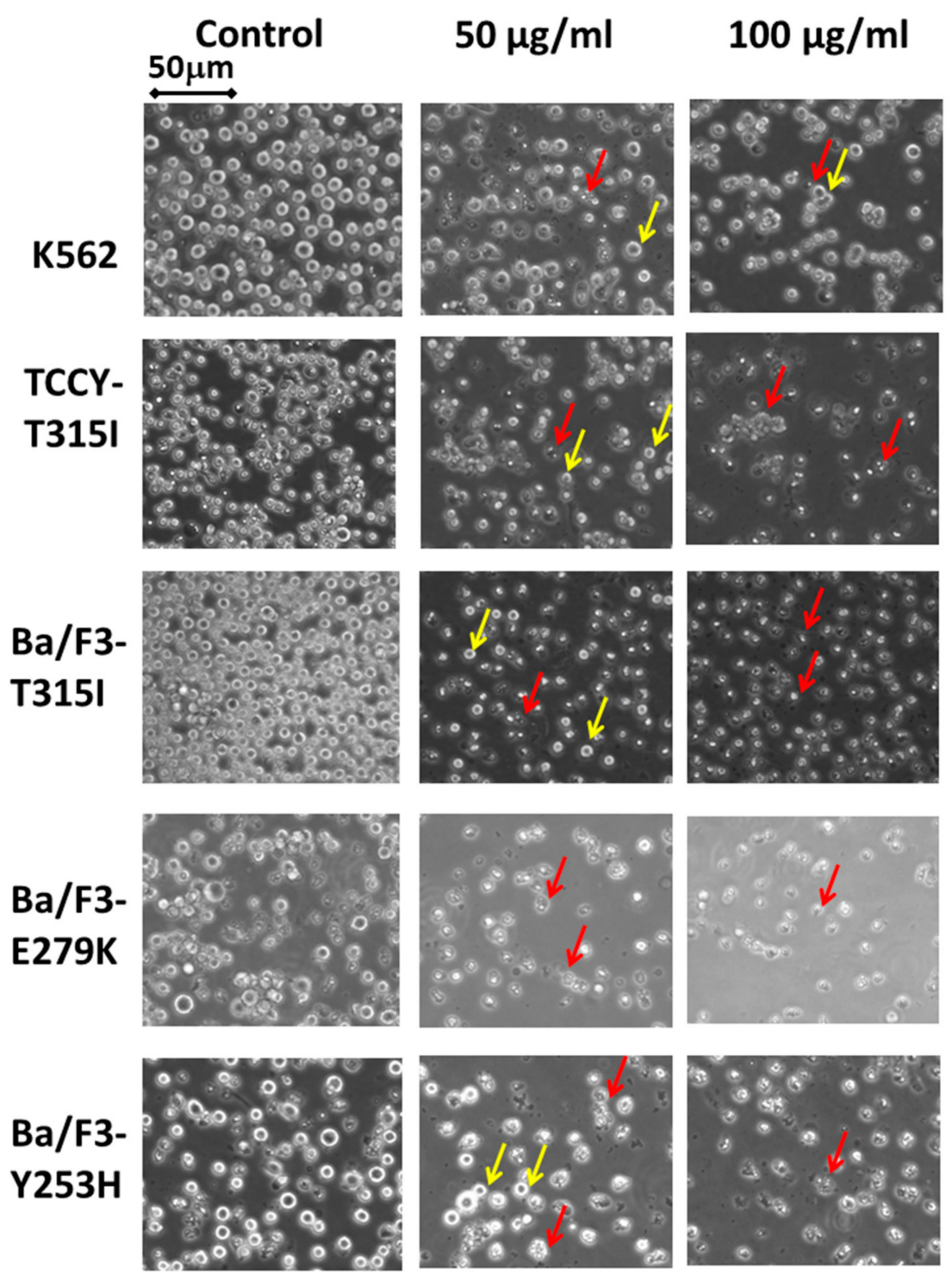

Figure 4. Morphological changes in cells by phase contrast microscope. K562, TCCY-T315I, Ba/F3T315I, Ba/F3-E279K and Ba/F3-Y253H cells were treated with 0, 50 or $100 \mu \mathrm{g} / \mathrm{mL}$ of MeST for $48 \mathrm{~h}$ and then observed under a phase contrast inverted microscope. (Intact cells are shown by a yellow arrow, debris cells are indicated by a red arrow.)

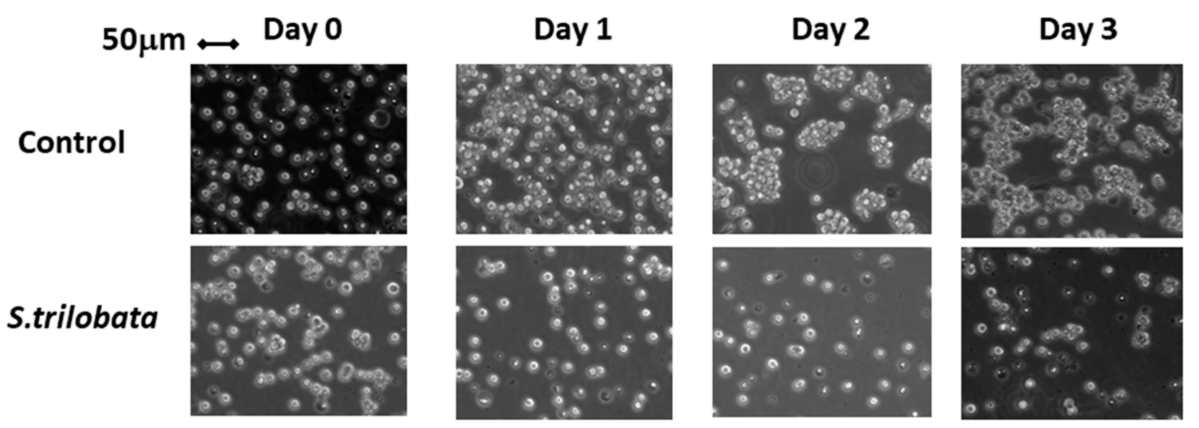

Figure 5. Morphological changes of TCCY-T315I by phase contrast microscope. TCCY-T315I cells were treated with $50 \mu \mathrm{g} / \mathrm{mL}$ of MeST for 24, 48 and $72 \mathrm{~h}$ and then observed under phase contrast inverted microscope. 
These findings suggested that MeST could induce apoptosis on leukemia cells.

\subsection{Apoptotic Cell Death Induced by MeST}

The growth inhibition after treatment with MeST could involve changes in the cell morphology, as demonstrated in Figures 1-4. In this experiment, we tested whether MeST treatment could also modify the expression of apoptotic markers. TCCY-T315I cells were treated with $50 \mu \mathrm{g} / \mathrm{mL}$ of MeST for up to $24 \mathrm{~h}$. The results show that MeST treatment caused the activation of caspase. Briefly, we found that PARP and caspase- 3 are cleaved in cells treated with $50 \mu \mathrm{g} / \mathrm{mL}$ of MeST (Figure 6A), and this result demonstrated that apoptosis happened. Next, we checked the nucleus morphology of cells. As shown in Figure 6B, the nucleus in cells treated with MeST is fragmented. In contrast, the nucleus is still intact in the control cells (untreated with MeST). Taken together, the cell death caused by MeST could be apoptosis.

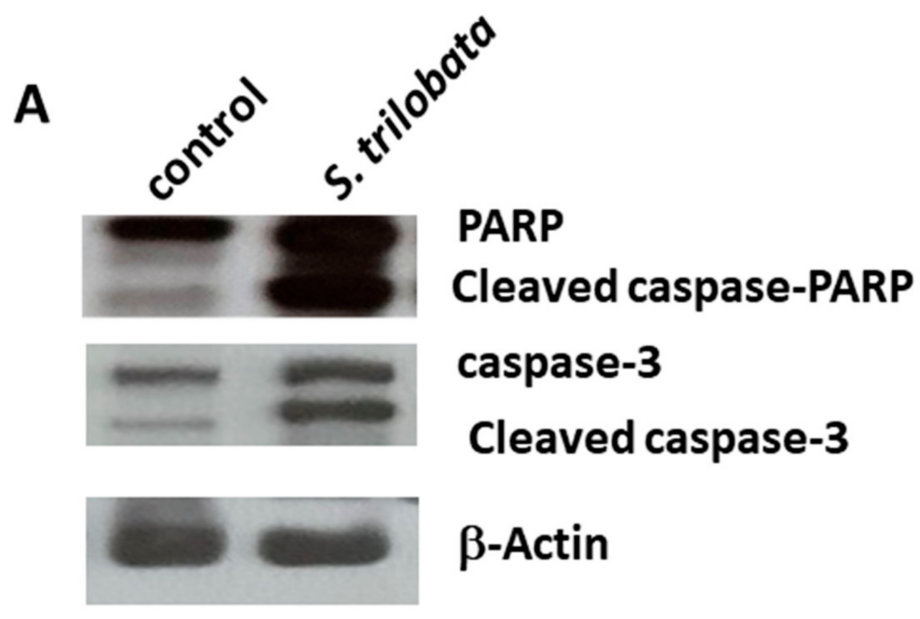

B

\section{Control}

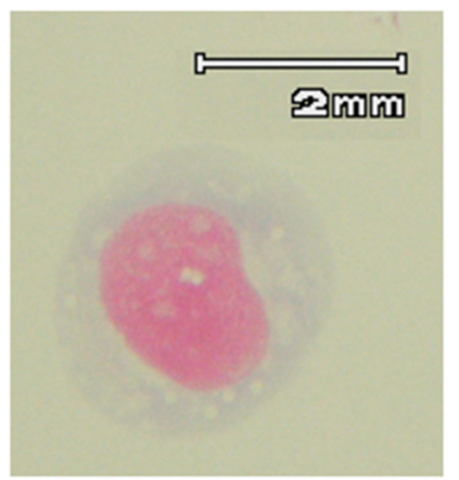

S. trilobata

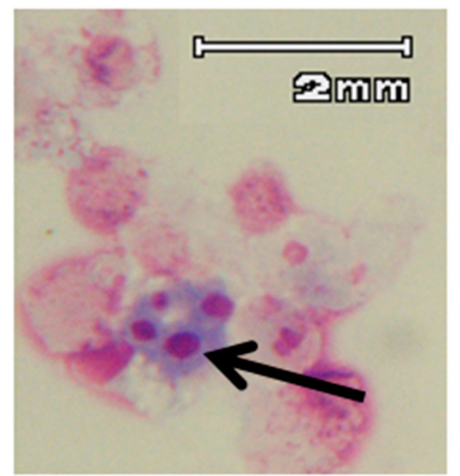

Figure 6. MeST could induce apoptosis in cells. (A) TCCY-T315I cells were treated with $50 \mu \mathrm{g} / \mathrm{mL}$ of MeST for up to $24 \mathrm{~h}$. Cell lysates were subjected to Western blot analysis with caspase-3 and PARP antibody. The results showed that treatment with MeST induced the cleavage of caspase- 3 and PARP. (B) The morphological changes of TCCY-T315I cells by MeST treatment. The arrow showed the appearance of apoptotic body in TCCY-T315I cells after $24 \mathrm{~h}$ treating with MeST.

\subsection{MeST Could Suppress the Expression of BCR/ABL}

$\mathrm{BCR} / \mathrm{ABL}$ is considered as a targeted marker for treatment. Because of its significance, we tested whether cells treated with MeST could have an effect on the expression of BCR/ABL. K562, BaF3/T315I, and TCCY-T315I cells were treated with various concentrations of MeST for $24 \mathrm{~h}$. As shown in Figure 7 (upper row), BCR/ABL expression 
is suppressed $24 \mathrm{~h}$ after treatment in a dose-dependent manner. Moreover, the downstream signaling of BCR/ABL, such as AKT and MAPK, is also affected and is compatible with the result of BCR/ABL suppression (Figure 7, middle row). This finding suggests that the antileukemia activity of MeST could act through the disruption of the BCR/ABL signaling cascade.

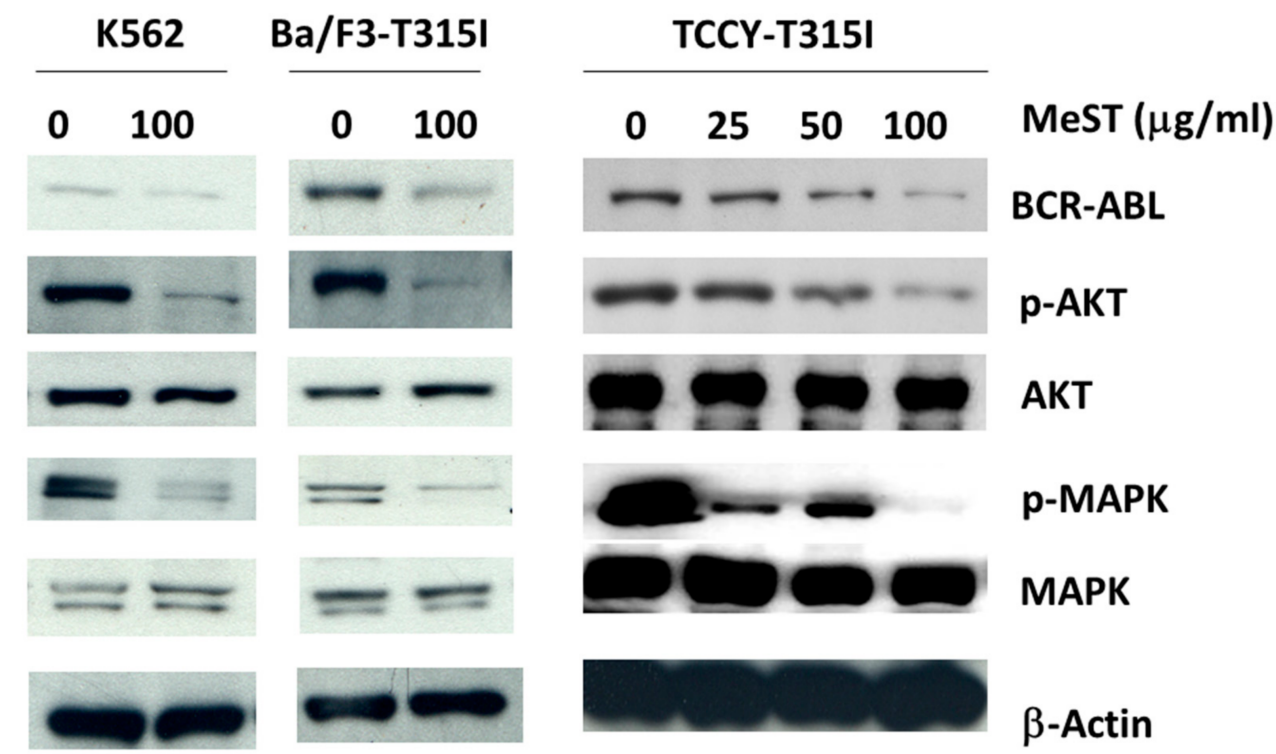

Figure 7. MeST could suppress the expression of BCR/ABL in cells. K562, BaF3/T315I, and TCCYT315I were treated with indicated concentrations of MeST or DMSO alone as a control. Total cell lysates were subjected to Western blot analysis with indicated antibodies.

\section{Discussion}

Cancer is concerned as the main reason of death all over the world owing to late diagnosis, poor prognosis or drug resistance. It is estimated that death caused by cancer will dramatically increase in the next decades. Despite the excellent finding of tyrosine kinasetargeted therapy for cancer treatment, such as imatinib for CML with BCR/ABL [21] or erlotinib for non-small-cell lung carcinoma [22], the resistance to the treatment still remains a difficult problem and there is a need to overcome it to get better healthcare. Natural compounds from plants get much attention from researchers because of the potential source of reagents for screening suitable candidates for clinical use. In fact, a great number of clinically active drugs that are used in cancer therapy are either natural products or based on natural products [23]. In this report, we observed the growth inhibitory effect of MeST on leukemia cells and the induction of apoptosis in CML cells by MeST. So far, it has been reported that MeST inhibited the growth of the human megakaryoblastic leukemia cell line MEG-01 with an $\mathrm{IC}_{50}$ value of around $80 \mu \mathrm{g} / \mathrm{mL}$ [16]. The water extract of S.trilobata collected in Hongkong killed more than 90\% of HL60 and K562 cells at a concentration of $200 \mu \mathrm{g} / \mathrm{mL}$ [17]. Thus, compared to previous studies, the results of our study show that S.trilobata collected in Vietnam is more sensitive to myeloid leukemia cells, with $100 \%$ of the cells having died after $48 \mathrm{~h}$ of being co-cultured with $100 \mu \mathrm{g} / \mathrm{mL}$ of MeST.

Apoptosis was based on some morphological changes in cell death including cell shrinkage, condensation of the chromatin, fragmentation of the nucleus, and blebbing of the membranes [24,25]. In this test, after two days of culturing, the treatment leukemia cells showed properties of apoptosis, such as cell shrinkage and membrane blebbing compared to untreated cells (Figures 1 and 2). Cellular shrinkage is one of the leading morphological features of almost all apoptotic cell death due to abnormal changes in the intracellular water [26]. Moreover, checking the apoptotic markers after treating with MeST has shown that the PARP cleavage $(89 \mathrm{kDa})$ and caspase- 3 cleavage are present after treatment. The results of these experiments confirmed that MeST could possess the antileukemia effect 
through a mechanism that could reverse the cells from uncontrolled growth to programmed cell death. The results also showed that the higher concentration of MeST exposed to the leukemia cells, the more damaging the cell morphology changes compared to control cells.

We found in this report that the effect of MeST could modify the expression of $\mathrm{BCR} / \mathrm{ABL}$ and therefore affect the activation of MAPK and AKT (Figure 7). It is well known that BCR/ABL is the oncoprotein and contributes to the development of leukemia. Based on this finding, the inhibitors of BCR/ABL are developed and successfully used in clinical treatment. However, other strategies of treatment have tried to suppress the expression of $\mathrm{BCR} / \mathrm{ABL}$ as an alternative option to block the signals of $\mathrm{BCR} / \mathrm{ABL}$. In this report, we observed that BCR/ABL is suppressed when cells are treated with MeST. Subsequently, the downstream signals of the BCR/ABL cascade are also affected. This observation could provide the mechanism of actions that MeST have on leukemia cells.

It is worthy to notice that the MeST has very little effect on the Vero cells (the normal monkey kidney) compared to the leukemia cells (Figure 3A). When calculating the SI value of leukemia cells or transfected Ba/F3 cells with the oncogene BCR/ABL, we found that MeST has a high selective effect on abnormal cells (Figure $3 \mathrm{~B}$ and Table 1).

\section{Materials and Methods}

\subsection{Plant Materials and Sample Extraction Preparation}

The fresh aerial parts of S.trilobata were collected in Hochiminh city (Vietnam) in 2017 and identified by Dr. My Van Dang, a herbalist of the Traditional Medicine Centre, Tinh Bien, An Giang province (the voucher number is HCM-2017-0114). The samples were washed and dried in a dry oven at $40{ }^{\circ} \mathrm{C}$ after collection until they got to a constant weight. The crude methanol extract was prepared as described in detail before [27]. The phytochemical analysis [28] showed that alkaloid, coumarin, flavonoid, anthocyanin, cardiac glycoside, tannin, reduced sugar, and polyuronide compounds have been seen in the S.trilobata extract.

\subsection{Cell Lines, Culture Conditions}

The human leukemia cell lines K562, TCCY-T315I and Ba/F3 were received from Prof. Yuko Sato (Tokyo, Japan). The Ba/F3 cells with T315I, Y253H and E279K were created as previous reported [20]. The African green monkey kidney (Vero) cell lineage (ATCC CCL$81^{\mathrm{TM}}$ ) was used in this study. Vero cells were grown in Dulbecco's modified Eagle's medium (DMEM, Sigma-Aldrich, Ho Chi Minh City, Vietnam) and other cells were grown in Roswell Park Memorial Institute 1640 medium (RPMI 1640, Sigma-Aldrich, Ho Chi Minh City, Vietnam) supplemented with $10 \%$ heat-inactivated fetal bovine serum (FBS) (ThermoFisher Scientific, Ho Chi Minh City, Vietnam), $100 \mathrm{IU} / \mathrm{mL}$ penicillin, and $0.1 \mathrm{mg} / \mathrm{mL}$ streptomycin (P4333, Sigma-Aldrich, Ho Chi Minh City, Vietnam) in a humidified incubator of $5 \% \mathrm{CO}_{2}$ at $37^{\circ} \mathrm{C}$.

\subsection{Cell Viability}

Cell proliferation was conducted on suspension cells and was determined by the trypan blue dye exclusion test as described previously [21].

All of the cells (K562, TCCY-T315I, Ba/F3-T315I, Y253H, and E279K) that live on the signal induced by BCR-ABL overexpression were used in the research, while the untransfected $\mathrm{Ba} / \mathrm{F} 3$ cells were not used because their growth was dependent on the signal induced by IL3. The selectivity index (SI) was expressed as $\mathrm{IC}_{50}$ value of Vero cell/IC 50 value of cancer cell line. The SI values indicate MeST selectively kill leukemia cells and not just non-selective cytotoxic extracts. Samples with an SI value $>3$ were considered highly selective for cancer cells [22].

\subsection{Morphological Changes of Cells by Phase-Contrast Microscope}

All cell lines excepted Vero cells were seeded in 6-well plates at a concentration of 105 cells per well and incubated overnight. Then, the cells were treated with different 
concentrations of $\operatorname{MeST}(0,50$ and $100 \mu \mathrm{g} / \mathrm{mL})$ followed by 48 -h or 72 -h incubation at $37{ }^{\circ} \mathrm{C}$ with $5 \% \mathrm{CO}_{2}$. The untreated cells served as a control. The morphological changes of the cells were observed using an inverted light microscope at $10 \times$ magnification.

\subsection{Western Blot Analysis}

Cells were plated onto $10 \mathrm{~cm}$ dishes at a density of $1 \times 10^{5}$ cells $/ \mathrm{mL}$ in the presence of various concentrations of reagents. After incubation for indicated durations, cells were collected and washed twice with PBS $(-)$. Cell protein was extracted and Western blot analysis was done as described previously [23]. A c-Abl (sc-23) antibody was obtained from Santa Cruz Biotechnology (Santa Cruz, CA, USA). Anti-actin (A2066) was obtained from SigmaAldrich. Then, p44/42 MAPK (Erk1/2), phospho-p44/42 MAPK (Thr202/Tyr204), AKT, phospho-AKT (Ser473), and caspase-3 antibodies were from Cell Signaling Technology Japan (Tokyo, Japan). Anti-PARP antibody was from WAKO Chemicals (Osaka, Japan).

\subsection{Statistics}

The data were analyzed using the unpaired Student's t-test between the control and compounds. A $p$ value $<0.05$ was considered statistically significant. Data were compiled from three independent experiments and values were expressed as mean \pm SD. For data calculations GraphPad prism software, version 8.3.0, (GraphPad Software Inc. HoChiMinh City, Vietnam) was used.

\section{Conclusions}

We propose that MeST could serve as a plant candidate for leukemia treatment. However, more studies need to be conduct in order to apply the benefit of MeST in practice.

Author Contributions: Conceptualization, B.T.K.L. and H.T.C.; methodology, B.T.K.L. and H.T.C.; software, B.T.K.L.; validation, B.T.K.L. and H.T.C.; formal analysis, N.T.L.T.; investigation, B.T.K.L. and H.T.C.; data curation, B.T.K.L. and H.T.C.; writing-original draft preparation, H.T.C.; writingreview and editing, B.T.K.L.; visualization, N.T.L.T. All authors have read and agreed to the published version of the manuscript.

Funding: This research is funded by Thu Dau Mot University under grant number DT.20.2-047.

Institutional Review Board Statement: Not applicable.

Informed Consent Statement: Not applicable.

Acknowledgments: We would like to thank Yuko Sato (the University of Tokyo, Japan), Hoang Thanh Chi (Thu Dau Mot University, Binh Duong Province, Vietnam) for providing the cell lines used in these studies.

Conflicts of Interest: The authors declare that they have no competing interests.

\section{References}

1. Chereda, B.; Melo, J.V. Natural course and biology of CML. Ann. Hematol. 2015, 94 (Suppl. 2), S107-S121. [CrossRef] [PubMed]

2. Hochhaus, A.; Larson, R.A.; Guilhot, F.; Radich, J.P.; Branford, S.; Hughes, T.P.; Baccarani, M.; Deininger, M.W.; Cervantes, F.; Fujihara, S.; et al. Long-Term Outcomes of Imatinib Treatment for Chronic Myeloid Leukemia. N. Engl. J. Med. 2017, 376, 917-927. [CrossRef] [PubMed]

3. Waller, C.F. Imatinib Mesylate. Recent Results Cancer Res. 2018, 212, 1-27.

4. Chandran, R.K.; Geetha, N.; Sakthivel, K.M.; Aswathy, C.G.; Gopinath, P.; Raj, T.V.A.; Priya, G.; Nair, J.K.K.M.; Sreedharan, H. Genomic amplification of BCR-ABL1 fusion gene and its impact on the disease progression mechanism in patients with chronic myelogenous leukemia. Gene 2019, 686, 85-91. [CrossRef] [PubMed]

5. Yurttaş, N.Ö.; Eşkazan, A.E. Novel therapeutic approaches in chronic myeloid leukemia. Leuk. Res. 2020, 91, 106337. [CrossRef] [PubMed]

6. Yan, Z.; Lai, Z.; Lin, J. Anticancer Properties of Traditional Chinese Medicine. Comb. Chem. High Throughput Screen. 2017, 20, 423-429. [CrossRef] [PubMed]

7. Long, Z.J.; Wang, L.X.; Zheng, F.M.; Chen, J.J.; Luo, Y.; Tu, X.X.; Lin, D.J.; Lu, G.; Liu, Q. A novel compound against oncogenic Aurora kinase A overcomes imatinib resistance in chronic myeloid leukemia cells. Int. J. Oncol. 2015, 46, 2488-2496. [CrossRef] [PubMed] 
8. Vo, V.C. Dictionary of Vietnamese Medicinal Plants; Medical PublishingHouse: Hanoi, Vietnam, 1997.

9. Loi, D.T. Vietnamese Medicinal Plants and Ingredients; Medical Publishing House: Hanoi, Vietnam, 2004.

10. Nam, N.H.; Kim, H.M.; Bae, K.H.; Ahn, B.Z. Inhibitory effects of Vietnamese medicinal plants on tube-like formation of human umbilical venous cells. Phytother. Res. 2003, 17, 107-111. [CrossRef] [PubMed]

11. Thu, N.B.; Trung, T.N.; Ha, D.T.; Khoi, N.M.; Hung, T.V.; Hien, T.T.; Yim, N.H.; Bae, K.H. Screening of Vietnamese medicinal plants for cytotoxic activity. Nat. Prod. Sci. 2010, 16, 43-49.

12. Tran, T.V.A.; Malainer, C.; Schwaiger, S.; Hung, T.; Atanasov, A.G.; Heiss, E.H.; Dirsch, V.M.; Stuppner, H. Screening of Vietnamese medicinal plants for NF- $\mathrm{kB}$ signaling inhibitors: Assessing the activity of flavonoids from the stem bark of Oroxylum indicum. J. Ethnopharmacol. 2015, 159, 36-42. [CrossRef]

13. Chethan, J.; Kumara, K.S.; Niranjana, S.R.; Prakash, H.S. Evaluation of antioxidant and antibacterial activities of methanolic flower extract of Wedelia trilobata (L.) Hitch. Afr. J. Biotechnol. 2012, 11, 9829-9834. [CrossRef]

14. Kade, I.J.; Barbosa, N.B.V.; Ibukun, E.O.; Igbakin, A.P.; Nogueira, C.W.; Rocha, J.B.T. Aqueous extracts of Sphagneticola trilobata attenuates streptozotocin-induced hyperglycaemia in rat models by modulating oxidative stress parameters. Biol. Med. 2010, 2, $1-13$.

15. Toppo, K.I.; Gupta, S.; Karkun, D.; Agrawal, S.; Kumar, A. Antimicrobial activity of Sphagneticola trilobata (1.) pruski, against some human pathogenic bacteria and fungi. Bioscan 2013, 8, 695-700.

16. Venkatesh, U.; Kollur, S.P.; Javarashetty, C.; Jayarama, S.; Murari, S.K. Methanolic Extract of Wedelia trilobata in Antiproliferation and Apoptotic Activity. Nat. Prod. Chem. Res. 2016, 4, 1-5. [CrossRef]

17. Nga-lam, Y.I.P. Antitumor Activities of Extracts and Fractions from Wedelia trilobata. Master Thesis, The Chinese University of Hong Kong, Hong Kong, China, 2002.

18. Mahavorasirikul, W.; Viyanant, V.; Chaijaroenkul, W.; Itharat, A.; Na-Bangchang, K. Cytotoxic activity of Thai medicinal plants against human cholangiocarcinoma, laryngeal and hepatocarcinoma cells in vitro. BMC Complementary Altern. Med. 2010, 10, 55. [CrossRef]

19. Doonan, F.; Cotter, T.G. Morphological assessment of apoptosis. Methods 2008, 44, 200-204. [CrossRef]

20. Model, M.A.; Schonbrun, E. Optical determination of intracellular water in apoptotic cells. J. Physiol. 2013, 591, 5843-5849. [CrossRef]

21. Mauro, M.J.; Druker, B.J. STI571: Targeting BCR-ABL as therapy for CML. Oncologist 2001, 6, 233-238. [CrossRef]

22. Herbst, R.S. Erlotinib (Tarceva): An update on the clinical trial program. Semin. Oncol. 2003, 30, 34-46. [CrossRef]

23. Cragg, G.M.; Pezzuto, J.M. Natural Products as a Vital Source for the Discovery of Cancer Chemotherapeutic and Chemopreventive Agents. Med. Princ. Pract. 2016, 25 (Suppl. 2), 41-59. [CrossRef]

24. Thuong, T.L.; Chi, T.; Ly, T.K. Evaluate anti-myeloid leukemia, antioxidants, and antimicrobials of Sphagneticola trilobata (L.) Pruski (Asteraceae). J. Buon 2021, 26. (in press).

25. Ly, B.T.K.; Chi, H.T. The potential effects of green tea (-)-epigallocatechin-3-gallate on overcoming imatinib-resistance in chronic myeloid leukemia bearing BCR-ABL. Ho Chi Minh City Univ. Educ. J. Sci. 2017, 14, 134-142.

26. Ly, B.T.K.; Chi, H.T.; Yamagishi, M.; Kano, Y.; Hara, Y.; Nakano, K.; Sato, Y.; Watanabe, T. Inhibition of FLT3 expression by green tea catechins in FLT3 mutated-AML cells. PLoS ONE 2013, 8, e66378. [CrossRef] [PubMed]

27. Ly, B.T.K.; Ly, D.M.; Linh, P.H.; Son, H.K.; Ha, N.L.; Chi, H.T. Screening of medicinal herbs for cytotoxic activity to leukemia cells. J. Buon 2020, 25, 1989-1996.

28. Thanh Chi, H.; Anh Vu, H.; Iwasaki, R.; Thao, L.B.; Hara, Y.; Taguchi, T.; Watanabe, T.; Sato, Y. Green tea (-)-epigalocatechin-3gallate inhibits KIT activity and causes caspase-dependent cell death in gastrointestinal stromal tumor including imatinib-resistant cells. Cancer Biol. Ther. 2009, 8, 1934-1939. [CrossRef] 